\title{
Medical Gas Purification
}

National Cancer Institute

\section{Source}

National Cancer Institute. Medical Gas Purification. NCI Thesaurus. Code C113062.

Separation of a gas mixture into purified component gases for medical use. 